\title{
Faktor-Faktor yang Mempengaruhi Pengungkapan Akuntansi Sumber Daya Manusia pada Perusahaan Perbankan di Indonesia Periode 2016-2018
}

\author{
Nur Afni Yunita \\ Universitas Malikussaleh \\ Yuni Mauliza \\ Universitas Malikussaleh \\ nurafni.yunita@unimal.ac.id
}

\begin{abstract}
Abstrak
Penelitian ini bertujuan untuk mengetahui pengaruh profitabilitas, diversifikasi produk, konsentrasi kepemilikan saham dan kepemilikan institusional terhadap pengungkapan akuntansi sumber daya manusia pada perusahaan perbankan di Indonesia. Sampel yang digunakan dalam penelitian adalah 20 perusahaan dengan total keseluruhan data pengamatan adalah 60 data. Analisis yang digunakan yaitu analisis regresi linear berganda. Hasil penelitian menunjukan bahwa variabel profitabilitas, konsentrasi kepemilikan saham dan institusional secara parsial tidak berpengaruh terhadap pengungkapan akuntansi sumber daya manusia. Sedangkan, variabel diversifikasi produk memiliki pengaruh terhadap pengungkapan akuntansi sumber daya manusia.
\end{abstract}

Kata Kunci : Profitabilitas, Diversifikasi Produk, Konsentrasi kepemilikan Saham, Kepemilikan Institusional, Pengungkapan Akuntansi Sumber Daya Manusia

\section{Pendahuluan}

Akuntansi Sumber Daya Manusia (SDM) adalah proses identifikasi dan pengukuran data mengenai sumber daya manusia serta pengkomunikasian informasi ke pihak-pihak yang berkepentingan. Sumber daya manusia dipandang sebagai asset yang sangat berharga karena visi, misi, strategi dan sistem perusahaan yang canggih sekalipun tidak akan berguna dan tidak memiliki dampak apapun terhadap perusahaan tanpa adanya sumber daya manusia yang berkualitas. Ikatan Akuntan Indonesia (IAI) dalam PSAK No. 19 mengidentifikasikan Aset adalah sumber daya yang dikendalikan oleh perusahaan sebagai akibat peristiwa masa lampau dan bagi perusahaan diharapkan akan menghasilkan manfaat ekonomis di masa depan.

Untuk bertahan dan berkembang di lingkungan yang berkompetisi dengan ketat maka perusahaan harus menjaga dan mengembangkan kualitas SDM. Menurut (2009) dalam Putri (2016) menyatakan bahwa SDM merupakan asset kritis dalam menentukan keberhasilan kegiatan perusahaan. SDM adalah energi, keterampilan, bakat dan pengetahuan untuk memproduksi suatu barang atau memberikan sebuah jasa yang berguna.

SDM yang handal dapat menciptakan keunggulan bersaing saat ini maupun di era mendatang. Dalam perusahaan, penyediaan laporan keuangan seperti perkiraan kas, aktiva tetap, aktiva berwujud dan tidak berwujud lainnya berada dalam kendali manusia. Hal ini mendorong perusahaan untuk meningkatkan kesadaran akan asset yang paling berharga dalam perusahaan yaitu SDM khususnya intellectual capital. Tanpa manusia, sumber daya perusahaan tidak akan mampu menghasilkan laba atau menambah nilainya sendiri. Manusialah 
yang mengelola suatu perusahaan dan manusia yang menciptakan nilai tambah bagi perusahaan (Harahap, 2007).

Hal ini tak sejalan dengan nilai untuk sumber daya manusia dalam laporan keuangan yang memiliki beberapa kelemahan dalam pengakuannya. Pengakuan nilai sumber daya manusia masih jarang terlihat atau ditemukan baik di neraca ataupun di laporan laba rugi. Semua biaya yang di keluarkan untuk sumber daya manusia itu dianggap sebagai biaya operasional bukan sebagai pengeluaran modal. Likert dan Pyle dalam (Widodo, 2014) menyatakan pengeluaran terkait sumber daya manusia lebih tepat disebut sebagai investasi sumber daya manusia. Pengeluaran yang dikeluarkan perusahaan selayaknya dilakukan pencatatan agar nantinya tersedia data tentang akuntansi sumber daya manusia.

Pengakuan tersebut juga kontradiksi jika dikaitkan dengan asumsi unit moneter. Dalam asumsi unit moneter akuntansi tidak memungkinkan untuk melaporkan nilai sumber daya manusia dalam laporan keuangan perusahaan karena sulit diukur dalam satuan moneter. Kondisi tersebut memunculkan tantangan untuk akuntan dalam mengukur dan mengidentifikasi sumber daya manusia serta melakukan komunikasi kepada pihak yang berkepentingan mengenai pengungkapan SDM di annual report (Al Mamun, 2009). Selanjutanya Pengungkapan akuntansi SDM juga sulit disampaikan kepada para stakeholders karena belum adanya standar yang mengatur tentang pengungkapan tersebut yang melemahkan nilai SDM dalam mempengaruhi keputusan.

Dari beberapa pemaparan diatas, mengenai kelemahan dalam pengakuan nilai SDM dalam laporan keuangan. Peneliti ingin mengakaji lebih mendalam mengenai faktor-faktor apa saja dan bagaimana pengaruhnya terhadap pengungkapan SDM dengan objek penelitian diambil pada perusahaan perbankan yang ada di Indonesia periode laporan keuangan $2016 \mathrm{sd}$ 2018, dengan judul penelitian "Faktor-faktor Yang Mempengaruhi Pengungkapan Akuntansi Sumber Daya Manusia Pada Perusahaan Perbankan Di Indonesia Periode 2016-2018”.

Rumusan masalah dan tujuan penelitian adalah untuk mengetahui apakah faktor-faktor yang mempengaruhi yang diwakilkan oleh variabel Profitabilitas, Diversifikasi Produk, Konsentrasi Kepemilikan Saham, dan Kepemilikan Institusional berpengaruh terhadap pengungkapan akuntansi SDM pada perusahaan perbankan periode tahun 2016-2018.

\section{Landasan Teori dan Pengembangan Hipotesis}

Resourced Based Theory merupakan teori pendukung yang melandasi dalam penelitian ini. Menurut pandangan Resource-Based Theory perusahaan akan unggul dalam persaingan usaha dan mendapatkan kinerja keuangan yang baik dengan cara memiliki, menguasai dan memanfaatkan aset-aset strategis yang penting (aset berwujud dan tidak berwujud). Strategi yang potensial untuk meningkatkan kinerja perusahaan adalah dengan menyatukan aset berwujut dan aset tidak berwujud. Berdasarkan pendekatan Resource-Based Theory dapat disimpulkan bahwa perusahaan harus memanfaatkan sumber daya yang dimiliki, hal ini akan mendorong perusahaan untuk melaporkannya (Widodo, 2014).

Teori kedua yang melandasi penelitian yaitu Legitimacy Theory. Teori legitimasi menganggap bahwa perusahaan akan berusaha mengesahkan citranya sebelum masyarakat menggunakan informasi (Patten, 1992; Hooghiemstra, 2000 dalam Cristy, 2015). Pengungkapan sosial merupakan penggunaan strategis dalam mengubah opini publik. Teori legitimasi banyak digunakan dalam menjelaskan pengungkapan sosial lingkungan. Dowling dan Prefer (1975) dalam Chariri (2011) menjelaskan bahwa teori legitimasi sangat bermanfaat dalam menganalisis perilaku organisasi. Menurut O'Donovan (2000) dalam Rahajeng (2010) 


\section{Nur Afni Yunita, Yuni Mauliza}

legitimasi organisasi dapat dilihat sebagai sesuatu yang diberikan masyarakat kepada perusahaan dan sesuatu yang diinginkan atau dicari oleh perusahaan dari masyarakat. Pengungkapan sumber daya manusia merupakan salah satu aspek dari pandangan Legitimacy Theory yang mengatur tentang kontrak perusahaan dengan masyarakat untuk melakukan kegiatan berdasarkan nilai-nilai justice, dan bagaimana perusahaan menanggapi berbagai kelompok kepentingan untuk melegitimasi tindakan perusahaan (Puasanti,2014). Hal ini dapat dijadikan sebagai sarana untuk mengonstruksikan strategi perusahaan, terutama terkait dengan upaya memposisikan diri di tengah lingkungan masyarakat yang semakin maju.

Akuntansi sumber daya manusia adalah proses mengidentifikasi dan mengukur data tentang sumber daya manusia serta mengkomunikasikan informasi ini kepada pihak yang berkepentingan (Al Mamun, 2009) . Sumber daya manusia dikategorikan sebagai aset tidak berwujud karena nilai manfaat dari SDM yang dinikmati oleh pesusahaan sehingga diakui sebagai aset tidak berwujud. Pengungkapan Akuntansi Sumber Daya Manusia berfungsi untuk meningkatnya pengakuan kepentingan melekat pemangku utama secara sosial dan perilaku korporasi bertanggung jawab terhadap lingkungan. Akuntansi sumber daya manusia telah membantu dalam memecahkan sebagian besar terkait masalah pegawai dalam organisasi perusahaan.

Sistem dan praktik-praktik investasi sumber daya manusia diyakini sukar ditiru oleh perusahaan lain atau dibeli begitu saja di pasar. Perilaku investasi sumber daya manusia memberikan dukungan pada argumen bahwa investasi pada sumber daya manusia merupakan sumber keunggulan bersaing yang potensial. Sistem yang memberlakukan investasi pada manusia dapat berpengaruh secara signifikan pada sumber daya dan individu di dalam perusahaan sehingga dapat menjadi salah satu faktor penting pencapaian keunggulan bersaing (Widodo,2014).

Profitabilitas menurut Kasmir (2012:195) adalah kemampuan perusahaan untuk menghasilkan laba. Kemampuan manajemen dengan tanggungjawabnya dalam menghasilkan laba harus diiringi dengan kemampuan dalam melaksanakan tanggung jawab sosialnya. Melalui pengungkapan sosial perusahaan berusaha mengkomunikasikan kepada stakeholder bahwa tidak hanya mencari laba semata, namun juga peduli kepada lingkungan dan sosialnya. Profitabilitas dapat diukur melalui beberapa alat ukr atau rasio, seperti Profit margin (profit margin on sales), Return on Investment (ROI), Return on Equit (ROE), Return on assets, dan Laba per lembar Saham

Profitabilitas adalah kemampuan perusahaan untuk menghasilkan laba. Kemampuan manajemen dengan tanggungjawabnya dalam menghasilkan laba harus diiringi dengan kemampuan dalam melaksanakan tanggungjawab kepada karyawannya yang merupakan aspek utama kesuksesan dari perusahaan. Selain itu dengan Kinerja ekonomi yang baik maka perusahaan akan mendapat dukungan lebih baik secara financial guna melakukan pengungkapan informasi SDM yang lebih luas untuk memuaskan stakeholder.

Tingkat profitabilitas merupakan indikator keberhasilan perusahaan terutama kemampuannya dalam menghasilkan laba dengan memanfaatkan sumber-sumber yang dimilikinya seperti aset dan ekuitas. Tingkat profitabilitas dalam penelitian ini didasarkan pada alasan bahwa ditemukan hubungan signifikan antara tingkat profitabilitas dengan luas pengungkapan informasi forward-looking dalam laporan tahunan perusahaan di UAE yang dilakukan Aljifri dan Hussainey dalam Kurniawan (2017).

Diversifikasi produk merupakan salah satu cara untuk meningkatkan volume penjualan yang dapat dilakukan oleh perusahaan terutama jika perusahaan tersebut telah berada dalam tahap kedewasaan. Menurut Kotler dan Armstrong (2008) diversifikasi merupakan strategi pertumbuhan perusahaan dengan cara memulai bisnis baru atau membeli perusahaan lain di 


\section{Nur Afni Yunita, Yuni Mauliza}

luar produk dan pasar perusahaan sekarang. Perusahaan harus tumbuh jika mereka ingin bersaing secara lebih efektif, memuaskan pemercaya (stakeholder), dan menarik sejumlah tenaga kerja yang berbakat (Kotler dan Armstrong, 2008). Kegiatan diversifikasi produk akan menimbulkan lebih banyak lagi informasi yang akan diungkapkan termasuk pengungkapan akuntansi sumber daya manusia atas kegiatan diversifikasi tersebut oleh perusahaan, hal ini merupakan rasa tanggung jawab perusahaan atas produk yang dihasilkannya.oleh karena itu informasi diversifikasi penting untuk memperoleh dukungan dari stakeholder mengenai rencana diversifikasi yang akan dilakukan perusahaan sehingga perusahaan juga harus meningkatkan pengungkapan sumber daya manusia.

Konsentrasi kepemilikan adalah sejumlah saham perusahaan yang tersebar dan dimiliki oleh beberapa pemegang saham yang nantinya pihak manajemen berkewajiban melaporkannya untuk beberapa kepentingan antara lain untuk perbaikan kebijakan perusahaan di masa mendatang dan pengambilan keputusan oleh pemegang saham RUPS (Puasanti, 2014). Konsentrasi kepemilikan terkait dengan jumlah pemegang saham atau besarnya persentase kepemilikan saham selain kepemilikan oleh publik di dalam struktur kepemilikan saham perusahaan. Apabila konsentrasi kepemilikan saham perusahaan tinggi dan didominasi oleh pemegang saham eksternal, masalah agensi dapat dikurangi. Konsentrasi kepemilikan dapat dihitung berdasarkan persentase kepemilikan saham terbesar yang dimiliki oleh pemegang saham tertinggi perusahaan (Jindal dan Manoj, 2012). Semakin tinggi konsentrasi kepemilikan, akan semakin tinggi pula kemampuan untuk mengendalikan perusahaan.

Kepemilikan Institusional adalah kepemilikan saham suatu perusahaan oleh institusi atau lembaga seperti perusahaan asuransi, bank, perusahaan investasi, dan kepemilikan institusi lainnya. Menurut Brealey, Myers, dan Marcus dalam Aini (2015) Kepemilikan Institusional adalah beberapa saham yang dipegang langsung oleh para investor individu tetapi proporsi yang besar dimiliki oleh lembaga keuangan seperti reksa dana, dana pensiun, dan perusahaan asuransi. Indikator yang digunakan untuk mengukur Kepemilikan Institusional adalah persentase jumlah saham, yang dimiliki pihak institusional dari seluruh modal saham perusahaan yang beredar (Amalia, 2015). Kepemilikan institusional sebagai mekanisme dalam corporate governance dapat meningkatkan kualitas keputusan investasi dalam tanggung jawab sosial, sehingga dapat meningkatkan nilai perusahaan dalam jangka panjang. Kepemilikan institusional yang semakin besar diharapkan dapat mendorong untuk mengungkapkan SDM perusahaan yang lebih luas (Sembiring, 2005). Semakin besar kepemilikan oleh institusi keuangan maka semakin besar pula kekuatan suara dan dorongan untuk mengoptimalkan Luas Pengungkapan SDM yang dilakukan oleh perusahaan (Wening dalam Puasanti 2014).

Berdasarkan pembahasan diatas, maka dapat digambarkan kerangka pemikiran (konseptual) mengenai Pengaruh profitabilitas, divesifikasi produk, konsentrasi kepemilikan saham dan kepemilikan Institusional terhadap Pengungkapan akuntansi sumber daya manusia sebagai berikut:

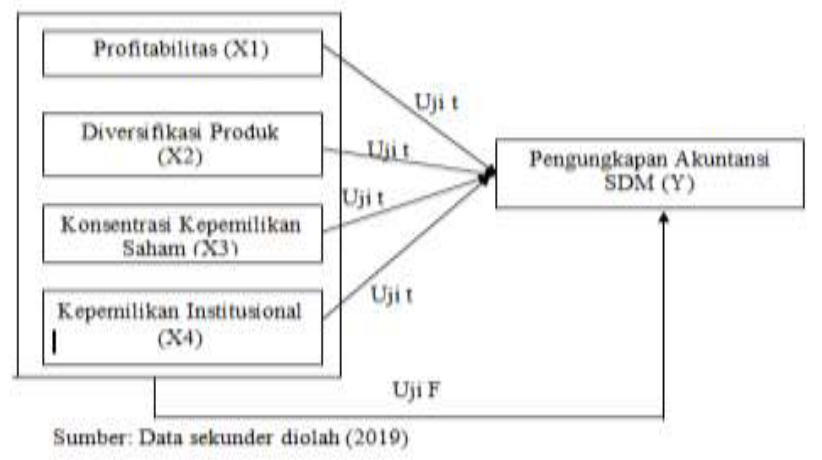

Gambar 1. Kerangka Pemikiran 
Berdasarkan uraian pada kerangka konseptual dan didukung dengan teori yang ada maka hipotesis penelitian ini adalah sebagai berikut:

H1 : Profitabilitas berpengaruh terhadap pengungkapan akuntansi SDM.

H2 : Diversifikasi produk berpengaruh terhadap pengungkapan akuntansi SDM.

H3 : Konsentrasi kepemilikan saham berpengaruh terhadap pengungkapan akuntansi SDM

H4 : Kepemilikan Institusional berpengaruh terhadap luas pengungkapan akuntansi SDM

\section{Metode Penelitian}

Objek penelitian dalam penelitian ini adalah Perusahaan perbankan yang terdaftar di Bursa Efek Indonesia (BEI) 2016-2018 . Data yang diperoleh dengan mencari langsung datadata mengenai Pengungkapan Akuntansi Sumber Daya Manusia yang dilakukan oleh perusahaan perbankan periode 2016 - 2018. Populasi yang di teliti dalam penelitian ini adalah seluruh perusahaan perbankan yang merupakan perusahaan perbankan periode 2016-2018 berjumlah 43 perusahaan. Sedangkan sampel digunakan melalui teknik pengambilan sampel dalam penelitian ini menggunakan metode porposive sampling. Porposive sampling yaitu teknik penentuan sampel dengan pertimbangan tertentu (Sugiyono, 2012:124).

Sampel yang digunkan dalam penelitian ini adalah Perusahaan Jasa Sektor Keuangan Sub Sektor Bank yang terdaftar di Bursa Efek Indonesia dengan kriteria bahwa Perusahaan Perbankan yang beturut-turut terdaftar di Bursa Efek Indonesia (BEI) periode 2016-2018 dan memiliki data kepemilikan saham. Berdasarkan metode diatas diperoleh dari populasi 43 didapatkan sampel 20 Perusahaan Perbankan (Perusahaan Jasa Sektor Keuangan Sub Sektor Bank) yang terdaftar di Bursa Efek Indonesia (BEI). Adapun perusahaan yang dijadikan sampel dalam penelitian ini adalah perusahaan perbankan yang diuraikan dalam Tabel 1. sebagai berikut:

Tabel 1. Daftar Sampel Penelitian

\begin{tabular}{|c|c|l|}
\hline No. & Kode & Nama \\
\hline 1. & AGRO & Bank Rakyat Indonesia Agroniaga Tbk \\
\hline 2. & BABP & PT Bank MNC Internasional Tbk. \\
\hline 3. & BBCA & Bank Central Asia Tbk \\
\hline 4. & BBKP & Bank Bukopin Tbk \\
\hline 5. & BBNI & Bank Negara Indonesia Tbk \\
\hline 6. & BBRI & Bank Rakyat Indonesia (Persero) Tbk \\
\hline 7. & BBTN & Bank Tabungan Negara (Persero) Tbk \\
\hline 8. & BJBR & $\begin{array}{l}\text { Bank Pembangunan Daerah Jawa Barat dan Banten } \\
\text { Tbk }\end{array}$ \\
\hline 9. & BMAS & PT Bank Maspion Indonesia Tbk. \\
\hline 10. & BMRI & Bank Mandiri (Persero) Tbk \\
\hline 11. & BNGA & Bank CIMB Niaga Tbk \\
\hline 12. & BNII & PT Bank Maybank Indonesia Tbk \\
\hline 13. & BNLI & Bank Permata Tbk \\
\hline 14. & BSIM & Bank Sinarmas Tbk \\
\hline 15. & BTPN & Bank Tabungan Pensiunan Nasional Tbk \\
\hline 16. & BVIC & Bank Victoria International Tbk \\
\hline 17. & INPC & Bank Artha Graha Internasional Tbk \\
\hline
\end{tabular}




\begin{tabular}{|c|c|l|}
\hline 18. & MEGA & Bank Mega Tbk \\
\hline 19. & NAGA & PT Bank Mitraniaga Tbk. \\
\hline 20. & PNBS & PT Bank Panin Dubai Syariah Tbk. \\
\hline
\end{tabular}

Pengukuran pengungkapan akuntansi SDM mengacu pada penelitian yang dikembangkan Widodo (2014). Dalam studi tersebut indeks variabel pengungkapan akuntansi SDM terdiri dari 16 item pelaporan dibangun dengan meninjau literatur yang relevan.

Tabel 2. Item Pengungkapan Akuntansi SDM

\begin{tabular}{|l|l|l|}
\hline No & Disclosure Items & \multicolumn{1}{c|}{ Item Pengungkapan } \\
\hline 1 & Separate HRA statement & Laporan SDM terpisah \\
\hline 2 & Total Value of Human resource & Nilai Total SDM \\
\hline 3 & Number of employees & Jumlah karyawan \\
\hline 4 & Human resource policy & Kebijakan SDM \\
\hline 5 & Training and development & Pelatihan dan Pengembangan \\
\hline 6 & Management succession plan & Rencana Suksesi Manajemen \\
\hline 7 & Employment report & Laporan Karyawan \\
\hline 8 & Employees' value addition & Nilai Tambah Karyawan \\
\hline 9 & Human resource development fund & Anggaran Pengembangan SDM \\
\hline 10 & Employees/workers fund & Anggaran Pekerja/Karyawan \\
\hline 11 & Employee categories & Kategori Karyawan \\
\hline 12 & Managerial remuneration & Remunerasi Manajerial \\
\hline 13 & Retirement benefits & Manfaat Persiun \\
\hline 14 & Performance Recognition & Pengakuan Kinerja \\
\hline 15 & Superannuation fund & Dana Pensiun \\
\hline 16 & Other employees benefits & Manfaat karyawan lainnya \\
\hline
\end{tabular}

Sumber : Al Mamun (2009),Widodo (2014) dan Puasanti (2014)

Dalam memeriksa setiap item akuntansi SDM ini, prosedur dikotomis diikuti di mana masing-masing perusahaan diberikan skor '1' jika perusahaan telah mengungkapkan variabel pelaporan yang bersangkutan dan '0' untuk sebaliknya. Rata-rata perusahaan kemudian dijumlah untuk menemukan nilai bersih setiap perusahaan. Rumus perhitungan pengungkapan akuntansi SDM adalah sebagai berikut (Widodo, 2014):

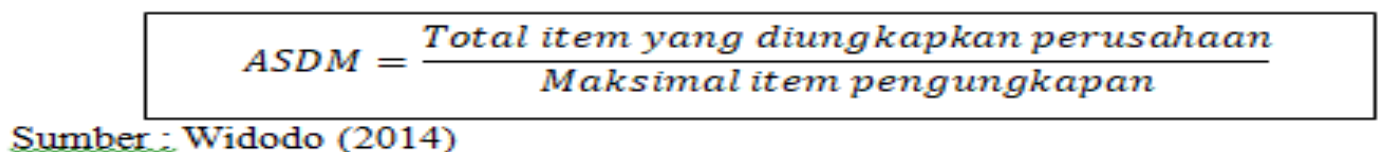

Sumber: Widodo (2014)

Dalam penelitian ini profitabilitas diukur dengan menggunakan Return On Assets (ROA). ROA menitik beratkan perhatian manajemen pada perolehan laba yang maksimal sebagaitolok ukur prestasi manajemen dalam memanfaatkan assets yang dimiliki perusahaan untuk memperoleh laba untuk mendorong tercapainya tujuan perusahaan. Return on assets dalam penelitian ini dapat diukur dengan rumus menurut (Kasmir, 2012) sebagai berikut:

$R O A=\frac{\text { Laba bersih Setelah pajak }}{\text { Total Asset }}$


Diversifikasi produk pada perusahaan perbankan dilakukan dengan mengembangkan produknya yang berupa jasa yang diminati pasar dan sesuai selera konsumen agar dapat meningkatkan penjualan dan profitabilitas. Dalam penelitian ini diversifikasi produk penulis mengacu pada jumlah jenis produk yang dihasilkan oleh perbankan seperti penelitian sebelumnya yang dilakukan widodo (2014), yaitu diukur dengan rumus sebagai berikut:

Diversifikasi produk $=$ jumlah jenis produk yang dihasilkan oleh perbankan

\section{Sumber: Widodo (2014)}

Konsentrasi kepemilikan menggambarkan tentang bagaimana dan siapa saja yang memegang kendali atas keseluruhan atau sebagian besar atas kepemilikan perusahaan serta keseluruhan atau sebagian besar pemegang kendali atas aktivitas bisnis perusahaan tersebut. Informasi mengenai konsentrasi kepemilikan saham dapat dilihat di laporan tahunan perusahaan pada Catatan atas laporan keuangan pada bagian Modal saham dimana pemegang saham terbesar merupakan pemilik yang mempunyai kendali atas perusahaan Ulfa (2016).

Ukuran konsentrasi kepemilikan suatu perusahaan diukur dengan menggunakan persentasi kepemilikan terbesar pada perusahaan yang menjadi sampel penelitian dengan rumus sebagai berikut:

$$
\text { Konsentrasi Kepemilikan }=\frac{\text { Jumlah Kepemili kan saham terbesar }(\text { dlm } l \text { br atau } R p)}{\text { Total Saham perusahaan }(\text { dlm } l b r \text { atau } R p)}
$$

\section{Sumber: Ulfa (2016)}

Kepemilikan Institusional adalah proporsi kepemilikan saham yang dimiliki institusional pada akhir tahun yang diukur dalam presentase saham yang dimiliki oleh investor institusional dalam suatu perusahaan seperti perusahaan asuransi, bank, dana pensiun, dan investment banking (Sukirni: 2012). Kepemilikan Institusional diukur melalui proporsi kepemilikan saham yang dimiliki institusional pada akhir tahun yang diukur dalam persentase saham yang dimiliki oleh investor institusional dalam suatu perusahaan. Kepemilikan Institusional dirumuskan sebagai berikut):

$$
\text { Kepemilikan Institusional }=\frac{\text { Jumlah Saham yang dimiliki Institusi }}{\text { Jumlah saham yang beredar }} \times 100 \%
$$

\section{Sumber: (Sukirni: 2012)}

Dalam penelitian ini, Metode analisis yang digunakan yaitu dengan menggunakan melakukan analisis kuantitatif yang di nyatakan dengan angka-angka yang dalam perhitungan menggunakan metode statistic yang di bantu dengan program pengolahan data statistikyang di kenal dengan SPSS versi 17.Tahapan-tahapan metode analisis yang digunakan dalam penelitian ini adalah statistik deskriptif dan uji kelayakan model regresi. Analisis regresi linear berganda ini digunakan untuk mengetahui pengaruh antara variabel independen, variabel dependen, dan variabel moderating, (Ghozali, 2016). Adapun rumusan persamaannya.

$$
Y=\alpha+b_{1} X_{1}+b_{2} X_{2}+b_{3} X_{3}+b_{4} X_{4}+e
$$


Keterangan :

$\begin{array}{ll}\text { Y } & \text { : Akuntansi Sumber Daya Manusia } \\ \mathrm{a} & \text { : Konstanta } \\ \mathrm{b} & \text { : Koefisien Regresi } \\ \mathrm{X} 1 & \text { : Profitabilitas } \\ \mathrm{X} 2 & \text { : Diversifikasi produk } \\ \mathrm{X} 3 & \text { : Konsentrasi Kepemilikan Saham } \\ \mathrm{X} 4 & \text { : Kepemilikan Institusional } \\ \mathrm{e} & \text { : Eror term }\end{array}$

Pengujian Hipotesis dilakukan dengan uji t, untuk melihat hubungan antara masingmasing variabel bebas terhadap variabel terikat. Jika hasil penelitian dan pengolahan data dijumpai nilai $\mathrm{t}$ hitung $>\mathrm{t}_{\text {tabel }}$ dengan tingkat signifikan 0,05 untuk masing-masing variabel, maka meliputi profitabilitas $\left(\mathrm{X}_{1}\right)$, diversifikasi produk $\left(\mathrm{X}_{2}\right)$, konsentrasi kepemilikan saham $\left(\mathrm{X}_{3}\right)$ dan kepemilikan institusional $\left(\mathrm{X}_{4}\right)$ secara parsial berpengaruh terhadap pengungkapan akuntansi sumber daya manusia (Y).

\section{Pembahasan}

Berdasarkan hasil analisis statistik deskriptif, maka berikut tabel hasil analisis variabel yang terdirri dari variabel dependen yaitu pengungkapan akuntansi sumber daya manusia dan variabel independen yaitu profitabilitas, diversifikasi produk, konsentrasi kepemilikan saham dan kepemilikan institusional. kemudian karakteristik dari sampel penelitian yang dibahas meliputi : jumlah sampel $(\mathrm{N})$, rata-rata (mean), nilai maksimum, nilai minimum serta standar deviasi. Deskriptif data variabel yang ada dalam penelitian ini dapat dilihat dalam tabel 4.

Tabel 4. Descriptive Statistics

\begin{tabular}{|l|r|r|r|r|r|}
\hline & \multicolumn{1}{|c|}{ N } & Minimum & \multicolumn{1}{c|}{$\begin{array}{c}\text { Maximu } \\
\text { m }\end{array}$} & \multicolumn{1}{c|}{ Mean } & \multicolumn{1}{c|}{$\begin{array}{c}\text { Std. } \\
\text { Deviation }\end{array}$} \\
\hline Pengungkapan_ASD & 60 & .1335 & .3747 & .227965 & .0678192 \\
M & 60 & -.2455 & .6830 & .293933 & .1788656 \\
Profitabilitas & 60 & .0038 & .5392 & .176823 & .1577107 \\
Diversivikasi_Produk & 60 & .0548 & .9332 & .581233 & .2598123 \\
Konsentrasi_Kepemili & & & & & .2751653 \\
kan & 60 & .0152 & .9736 & .487030 &. \\
Kepemilikan_Institusi & & & & \\
onal & 60 & & & & \\
Valid N (listwise) & & &
\end{tabular}

\section{Analisis Regresi Linear Berganda}

Penelitian ini bertujuan untuk mengetahui pengaruh profitabilitas, diversifikasi produk, konsentrasi kepemilikan saham dan kepemilikan institusional terhadap pengungkapan akuntansi sumber daya manusia pada Perusahaan Perbankan di Indonesia. Oleh karena itu digunakan analisis regresi linear berganda untuk menganalisis pengaruhnya. Hasil analisis linear berganda dengan program SPSS versi 22 diperoleh sebagai berikut: 
Tabel 7. Hasil Regresi Linear Berganda

\begin{tabular}{|ll|r|r|r|r|r|}
\hline \multirow{2}{*}{ Model } & \multicolumn{2}{|c|}{$\begin{array}{c}\text { Unstandardized } \\
\text { Coefficients }\end{array}$} & $\begin{array}{c}\text { Standardized } \\
\text { Coefficients }\end{array}$ & \multirow{2}{*}{} & \\
\cline { 2 - 4 } & \multicolumn{1}{|c|}{ B } & Std. Error & \multicolumn{1}{c|}{ Beta } & \multicolumn{1}{c|}{ Sig. } \\
\hline 1 & (Constant) & .175 & .043 & & 4.025 & .000 \\
& Profitabilitas & .047 & .053 & .124 & .890 & .378 \\
& Diversivikasi_Produk & .114 & .063 & .266 & 1.804 & .077 \\
& Konsentrasi_Kepemilikan & .025 & .038 & .097 & .664 & .510 \\
& Kepemilikan_Institusional & .009 & .035 & .035 & .249 & .804 \\
\hline
\end{tabular}

a. Dependent Variable: Pengungkapan_ASDM

Berdasarkan Tabel 4.5 di atas dapat dilihat koefisien dari masing-masing variabel dan konstanta yang menjadi observasi dalam penelitian ini adalah koefisien Profitabilitas $\left(\mathrm{X}_{1}\right)$ 0,047, Diversifikasi Produk $\left(\mathrm{X}_{2}\right)$ 0,114, Konsentrasi Kepemilikan Saham ( $\left.\mathrm{X}_{3}\right)$ 0,025, Kepemilikan Institusional $\left(\mathrm{X}_{4}\right)$ 0,009, dan konstanta 0,175 Hal ini berarti variabel independen berpengaruh terhadap pengungkapan Akuntansi Sumber Daya Manusia . Secara persamaan dapat ditulis sebagai berikut:

\section{$Y=0,175+0,047 X_{1}+0,114 X_{2}+0,025 X_{3}+0,009 X_{4}+e$}

Dari persamaan tersebut dapat dijelaskan bahwa pengaruh profitabilitas, diversifikasi produk, konsentrasi kepemilikan saham dan kepemilikan institusional terhadap Pengungkapan akuntansi sumber daya manusia. Dari hasil analisis menunjukkan bahwa:

a. Konstanta $(\alpha)$ sebesar 0,175 , hal ini menyatakan bahwa jika tidak ada pengaruh (peningkatan/penurunan) nilai variabel $\mathrm{X}_{1}, \mathrm{X}_{2}, \mathrm{X}_{3}$, dan $\mathrm{X}_{4}$, maka Pengungkapan akuntansi sumber daya manusia adalah sebesar $17,5 \%$.

b. Nilai Koefisien Variabel Profitabilitas $\left(b_{1}\right)$ bernilai positif, yaitu sebesar 0,047 dimana hubungan variabel profitabilitas merupakan hubungan positif, pada setiap peningkatan Profitabilitas $\left(\mathrm{X}_{1}\right)$ sebesar 1\%, maka akan meningkatkan Pengungkapan akuntansi sumber daya manusia sebesar $0,047(4,7 \%)$ begitu juga sebaliknya dengan asumsi variabel independen lainnya tetap.

c. Nilai Koefisien Variabel Diversifikasi Produk $\left(b_{2}\right)$ bernilai positif, yaitu sebesar 0,114 , dimana hubungan variabel Diversifikasi Produk merupakan hubungan positif, setiap peningkatan Diversifikasi Produk $\left(\mathrm{X}_{2}\right)$ sebesar 1\%, maka akan meningkatkan Pengungkapan akuntansi sumber daya manusia sebesar 0,114 (11,4\%).

d. Nilai Koefisien Variabel Konsentrasi Kepemilikan Saham $\left(b_{3}\right)$ bernilai positif, pada setiap peningkatan Konsentrasi Kepemilikan Saham $\left(\mathrm{X}_{3}\right)$ sebesar 1\%, maka akan meningkatkan Pengungkapan akuntansi sumber daya manusia sebesar 0,025 (2,5\%). begitu juga sebaliknya.

e. Nilai Koefisien Variabel Kepemilikan Institusional $\left(b_{1}\right)$ bernilai positif, yaitu sebesar 0,009, dimana hubungan variabel Kepemilikan Institusional Saham merupakan hubungan positif, pada setiap peningkatan Kepemilikan Institusional $\left(\mathrm{X}_{4}\right)$ sebesar $1 \%$, maka akan meningkatkan Pengungkapan akuntansi sumber daya manusia sebesar 0,009 (0,9\%) begitu juga sebaliknya 


\section{Hasil Pengujian Hipotesis}

Hasil pengujian hipotesis dapat dilihat pada Tabel 8. berikut

Tabel 8. Hasil Pengujian Hipotesis

\begin{tabular}{|c|c|c|c|c|c|}
\hline \multirow[b]{2}{*}{ Model } & \multicolumn{2}{|c|}{$\begin{array}{c}\text { Unstandardized } \\
\text { Coefficients }\end{array}$} & $\begin{array}{c}\text { Standardized } \\
\text { Coefficients }\end{array}$ & \multirow[b]{2}{*}{$\mathrm{t}$} & \multirow[b]{2}{*}{ Sig. } \\
\hline & $\mathrm{B}$ & Std. Error & Beta & & \\
\hline $1 \quad$ (Constant) & .175 & .043 & & 4.025 & .000 \\
\hline Profitabilitas & .047 & .053 & .124 & .890 & .378 \\
\hline Diversivikasi_Produk & .114 & .063 & .266 & 1.804 & .077 \\
\hline Konsentrasi_Kepemilikan & .025 & .038 & .097 & .664 & .510 \\
\hline Kepemilikan_Institusional & .009 & .035 & .035 & .249 & .804 \\
\hline
\end{tabular}

a. Dependent Variable: Pengungkapan_ASDM

Dari tabel diatas, maka dapat dilihat bahwa untuk H1 didapatkan hasil bahwa nilai thitung $_{\text {. }}$ pada persamaan regresi linear berganda sebesar 0,980 dan $\mathrm{t}_{\text {tabel }(\mathrm{n}-2,5 \% \text { uji dua pihak })}=1.672$ di mana $t_{\text {hitung }}<\mathrm{t}_{\text {tabel }}(0,980<1.672)$ dengan nilai signifikansi $(0,378>0,05)$. Sehingga hipotesis pertama $\left(\mathrm{H}_{1}\right)$ ditolak. Artinya Profitabilitas $\left(\mathrm{X}_{1}\right)$ tidak berpengaruh terhadap Pengungkapan Akuntansi Sumber Daya Manusia perusahaan Perbankan di Indonesia. Hal ini berarti bahwa variabel profitabilitas tidak berpengaruh terhadap pengungkapan akuntansi sumber daya manusia. Sehingga dapat disimpulkan tingkat profitabilitas tidak mampu meningkatkan pengungkapan akuntansi sumber daya manusia.

Hasil yang menunjukkan tidak adanya pengaruh profitabilitas terhadap pengungkapan akuntansi sumber daya manusia ini disebabkan karena dari 20 perusahaan perbankan di Indonesia 17 perusahaan perbankan mengalami pergerakan profitabilitas yang meningkat sementara pengungkapan akuntansi sumber daya manusianya tidak mengalami peningkatan sehingga menimbulkan hasil yang tidak berpengaruh pada objek yang diteliti pada penelitian ini. Temuan penelitian ini sejalan dengan penelitian yang dilakukan Ulfa (2016) dan Cristy (2015) yang menemukan bahwa Profitabilitas tidak berpengaruh terhadap Pengungkapan Akuntansi SDM. Namun penelitian ini tidak sejalan dengan penelitian yang dilakukan oleh hasil penelitian yang dilakukan oleh Kurniawan (2017) dan Amalia (2016) yang menemukan bahwa Profitabilitas berpengaruh terhadap Pengungkapan Akuntansi SDM.

Untuk H2 didapatkan hasil Secara parsial (uji t) yang diperoleh dari nilai thitung pada persamaan regresi linear berganda sebesar 1,804 dan $t_{\text {tabel }(n-2,5 \% \text { uji dua pihak) }}=1,672$ di mana $t_{\text {hitung }}>t_{\text {tabel }}(1,804>1,672)$ dengan nilai signifikansi $(0,077>0,05)$. Sehingga hipotesis Kedua $\left(\mathrm{H}_{2}\right)$ diterima. Artinya Diversifikasi Produk berpengaruh tidak signifikan terhadap Pengungkapan Akuntansi Sumber Daya Manusia perusahaan Perbankan di Indonesia. Hasil penelitian ini menunjukkan bahwa secara parsial Diversifikasi Produk berpengaruh tidak signifikan terhadap Pengungkapan Akuntansi SDM Hal ini berarti hipotesis $\mathrm{H}_{2}$ (Diversifikasi Produk berpengaruh terhadap Pengungkapan Akuntansi SDM) diterima. Berdasarkan hasil penelitian diketahui bahwa jumlah produk yang berbeda dari perbankan berdasarkan klasifikasi yang dilakukan menggambarkan hubungan langsung dengan pengungkapan SDM karena pada dasarnya kecenderungan yang dilakukan oleh perusahaan akan diversifikasi produk yang dimiliki adalah mendapatkan perhatian nasabah akan layanan-layanan yang ditawarkan.

Strategi diversifikasi yang dilakukan perusahaan umumnya mendorong pengungkapan informasi tambahan dalam laporan tahunan. Sehingga kegiatan diversifikasi produk akan menimbulkan lebih banyak lagi informasi yang akan diungkapkan termasuk pengungkapan akuntansi sumber daya manusia atas kegiatan diversifikasi tersebut oleh perusahaan. Hasil 
Penelitian ini sesuai dengan penelitian penelitian yang dilakukan Amalia (2015) dan Widodo (2014) memberikan hasil bahwa diversifkasi produk berpengaruh terhadap pengungkapan akuntansi sumber daya manusia. Dan berbeda dengan Cristy (2015) yang menemukan bahwa diversifikasi produk tidak berpengaruh terhadap pengungkapan akuntansi sumber daya manusia.

Hasil H3 didaptkan bahwa Secara parsial (uji t) yang diperoleh dari nilai $t_{\text {hitung }}$ pada persamaan regresi linear berganda sebesar 0,664 dan $t_{\text {tabel }(n-2,5 \% \text { uji dua pihak) }}=1,672$ di mana $\mathrm{t}_{\text {hitung }}<\mathrm{t}_{\text {tabel }}(0,664<1.672)$ dengan nilai signifikansi $(0,520>0,05)$. Sehingga hipotesis ketiga $\left(\mathrm{H}_{3}\right)$ ditolak. Artinya Konsentrasi Kepemilikan Saham $\left(\mathrm{X}_{3}\right)$ tidak berpengaruh terhadap Pengungkapan Akuntansi Sumber Daya Manusia perusahaan Perbankan di Indonesia. Hasil yang menunjukkan tidak adanya pengaruh konsentrasi kepemilikan saham terhadap pengungkapan akuntansi sumber daya manusia ini disebabkan karena seluruh pusahaan perbankan di Indonesia memilki jumlah konsentrasi kepemilikan saham yang semakin meningkat yang meningkat sementara pengungkapan akuntansi sumber daya manusianya tidak mengalami peningkatan sehingga menyebabkan tidak adanya pengaruh antara konsentrasi kepemilikan saham terhadap pengungkapan akuntansi sumber daya manusia objek yang diteliti pada penelitian ini. Hasil Penelitian ini sesuai dengan hasil penelitian yang dilakukan oleh Ulfa (2016), Pramuna(2012), Suta (2012) dan Saputra (2012) yang menemukan bahwa konsentrasi kepemilikan tidak berpengaruh terhadap pengungkapan akuntansi SDM perusahaan. Dan berbeda dengan hasil penelitian yang dilakukan oleh Puasanti (2014), Dominguez (2012), Darmawati (2006) dan Kinnon (2007) yang menemukan bahwa Konsentrasi Kepemilikan Saham berpengaruh terhadap pengungkapan akuntansi sumber daya manusia.

Selanjutnya untuk Hasil H4 didapatkan bahwa nilai thitung pada persamaan regresi linear berganda sebesar 0,249 dan $t_{\text {tabel }(n-2,5 \%}$ uji dua pihak $)=1.672$ di mana $t_{\text {hitung }}<t_{\text {tabel }}(0,249<1.672)$ dengan nilai signifikansi $(0,804<0,05)$. Sehingga hipotesis keempat $\left(\mathrm{H}_{4}\right)$ ditolak. Artinya Kepemilikan Institusional $\left(\mathrm{X}_{4}\right)$ tidak berpengaruh terhadap Pengungkapan Akuntansi Sumber Daya Manusia perusahaan Perbankan di Indonesia. Perusahaan Perbankan perlu memiliki Monitor dari pihak institusi untuk menjamin kemakmuran pemegang saham, pengaruh kepemilikan institusional sebagai agen pengawas ditekan melalui investasi mereka yang cukup besar dalam pasar modal. Tingkat kepemilikan institusional yang tinggi akan menimbulkan usaha pengawasan yang lebih besar oleh pihak investor institusional sehingga dapat menghalangi perilaku manajer yang mementingkan kepentingannya sendiri yang pada akhirnya akan merugikan pemilik perusahaan. Semakin besar kepemilikan oleh institusi keuangan maka semakin besar pula kekuatan suara dan dorongan karena informasi yang dibutuhkan oleh pemegang saham untuk mengoptimalkan Luas Pengungkapan SDM yang dilakukan oleh perusahaan perbankan di Indonesia. Hasil penelitian ini sesuai dengan hasil penelitian yang dilakukan oleh Ulfa (2016), Pramuna (2013), Suta (2012) dan Saputra (2014) yang menemukan bahwa Kepemilikan Institusional tidak berpengaruh terhadap pengungkapan akuntansi SDM perusahaan dan berbeda dengan hasil penelitian yang dilakukan oleh Puasanti (2014), (Rosiana, 2013), dan Lestari (2011) yang menemukan bahwa Kepemilikan Institusional berpengaruh terhadap pengungkapan akuntansi sumber daya manusia.

\section{Kesimpulan}

Berdasarkan penelitian yang dilakukan pada Perusahaan Perbankan di Indonesia tahun 2016-2018, dari hasil pengujian hipotesis didapatkan hasil bahwa secara parsial Profitabilitas, Konsentasi Kepemilikan Saham, dan Kepemilikan Institusional tidak berpengaruh terhadap Pengungkapan Akuntansi Sumber Daya Manusia dengan kata lain H1,H3,H4 ditolak. 
Sedangkan $\mathbf{H 2}$ diterima dimana Diversifikasi Produk memiliki pengaruh terhadap Pengungkapan Akuntansi Sumber Daya Manusia.

Daftar Pustaka

Aini. (2015). Pengaruh Kepemilikan Manajerial Terhadap Pengungkapan Sukarela Dengan Efektivitas Komite Audit Sebagai Variabel Moderasi

Al Mamun, Syed Abdulla. (2009). Human Resource Accounting (HRA) Disclosure Of Bangladeshi Companies And Its Association With Corporate Characteristics. BRAC University Journal, vol. V1, no. 1, pp. 35- 43

Amalia (2015) Pengaruh Karakteristik Perusahaan Terhadap Pengungkapan Akuntansi

Sumber Daya Manusia (Studi pada perusahaan non-keuangan yang terdaftar di

Bursa Efek Indonesia periode 2011-2013

Chariri dan Ghozali, Ahmad. 2011. Teori Akuntansi. Yogyakarta: Andi

Cristy (2015) Pengaruh Karakteristik Perusahaan Terhadap Pengungkapan Akuntansi

Sumber Daya Manusia Pada Perusahaan Manufaktur Yang Terdaftar Di Bursa Efek Indonesia Tahun 2011-2013

Ghozali, Imam. 2016. Analisis Multivariate Dengan Program SPSS. Semarang. Badan Penerbit Universitas Diponegoro

Harahap, 2007, Analisis Kritis Atas Laporan Keuangan, edisi Pertama, cetakan ketiga, Penerbit : Raja Grafindo Persada, Jakarta

Kasmir. 2012. Analisis Laporan Keuangan. Jakarta: PT. Raja Grafindo Persada.

Kotler, Philip; Armstrong, Garry, 2008. Prinsip-prinsip Pemasaran, Jilid 1, Erlangga, Jakarta

Kurniawan (2017) Analisis Pengaruh Profitabilitas, Umur Perusahaan Dan Leverage

Terhadap Pengungkapan Akuntansi Sumber Daya Manusia (Studi Empiris Pada Perusahaan Manufaktur Sektor Industri Barang Konsumsi Yang Terdaftar Di Bursa Efek Indonesia Periode 2012-2015)

Lestari, H. 2011. Pengaruh Struktur Kepemilikan terhadap Luas Pengungkapan Tanggung Jawab Sosial Perusahaan (CSR Disclosure).Skripsi. Universitas Islam Sultan Agung, Semarang.

Pramuna, R. danRaharja, S. 2013. Dampak Pengungkapan Sumber Daya Manusia terhadap Reputasi Perusahaan. Diponegoro Journal of Accounting.Vol.2, No. 3, Hal.1-12

Puasanti (2014) Pengaruh Ukuran Perusahaan, Umur Perusahaan, Konsentrasi Kepemilikan, Komisaris Independen, dan Leverage terhadap Pengungkapan Modal Intelektual

Putri, Meidera Elsa Dwi. (2016). Pengaruh Profitabilitas, Struktur Aktiva dan Ukuran Perusahaan terhadap Struktur Modal pada Perusahaan Manufaktur Sektor Industri Makanan dan Minuman yang terdaftar di Bursa Efek Indonesia" Universitas Negeri Padang, Jurnal Manajemen, Vol.01, No.01, Hal 1-10.

Rahajeng E, Tuminah S (2010). Prevalensi Hipertensi dan Determinannya di Indonesia. Jakarta: Pusat Penelitian Biomedis dan Farmasi Badan Penelitian Kesehatan Departemen Kesehatan RI. 
Rosiana, Gusti Ayu, Gede Juliarsyah dan Maria M. Ratna Sari (2013). Pengaruh Pengungkapan CSR Terhadap Nilai Perusahaan dengan Pofitabilitas sebagai Variabel Pemoderasi. E- Jurnal Akuntansi Universitas Udayana 5.3 (2013);723-738 Saputra, KAK (2014) The Effect Of Emotional Spiritual Quotient (ESQ) To Ethical Behavior In Accounting Profession With Tri Hita Karana Culture's As A Moderating Variable. Research Journal of Finance Vol 5, No.7

Sembiring, E. R. (2005). Karakteristik Perusahaan dan Pengungkapan Tanggung Jawab

Sosial : Study pada Perusahaan yang Tercatat di Bursa Efek Jakarta. Simposium Nasional Akuntansi VIII. Solo, (September), 15-16

Sugiyono. 2012. Metode Penelitian Kuantitatif Kualitatif dan R\&D. Bandung: Alfabeta.

Suta A.Y, and H. Laksito, "Analisis Faktor-Faktor Yang Mempengaruhi Luas Pengungkapan Informasi Sukarela Laporan Tahunan (Studi Empiris Pada Perusahaan Manufaktur yang Terdaftar di Bursa Efek Indonesia Tahun 20082010)," Diponegoro Journal of Accounting, vol. 1, no. 1, pp. 38-46, Oct. 2012.

Ulfa (2016) Pengaruh Karakteristik Perusahaan terhadap Pengungkapan Akuntansi Sumber Daya Manusia (Studi Empiris pada Perusahaan Sektor Keuangan, IT, dan Farmasi Terdaftar di Bursa Efek Indonesia Tahun 2013 Dan 2014)

Widodo, Nova Maulud. 2014. Pengaruh Karakteristik Perusahaan terhadap Pengungkapan Akuntansi sumber daya Manusia. Simposium Nasional Akuntansi XVII, Mataram 